\title{
Rho/Rho-associated kinase pathway in glaucoma (Review)
}

\author{
JING WANG $^{*}$, XIAOHONG LIU* ${ }^{*}$ and YISHENG ZHONG \\ Department of Ophthalmology, Ruijin Hospital Affiliated Medical School, \\ Shanghai Jiaotong University, Shanghai 200025, P.R. China
}

Received July 9, 2013; Accepted August 21, 2013

DOI: $10.3892 /$ ijo.2013.2100

\begin{abstract}
The Rho/ROCK pathway plays important roles in the modulation of the cytoskeletal integrity of cells, the synthesis of extracellular matrix components in the aqueous humor outflow tissue and the permeability of Schlemm's canal endothelial cells. The activation of the Rho/ROCK pathway results in trabecular meshwork (TM) contraction, and the inhibition of this pathway would provoke relaxation of TM with subsequent increase in outflow facility and, thereby, decrease intraocular pressure (IOP). ROCK inhibitors also serve as potent anti-scarring agents via inhibition of transdifferentiation of tenon fibroblasts into myofibroblasts. Furthermore, the RhoA/ROCK pathway is involved in optic nerve neuroprotection. Inactivation of Rho/ROCK signaling increase ocular blood flow, improve retinal ganglion cell (RGC) survival and promote RGC axon regeneration. Considering the IOP modulation, potent bleb anti-scarring effect and neuroprotective properties of ROCK inhibitors, the Rho/ROCK pathway is an attractive target for anti-glaucoma therapy, and it may be used for human therapy in the near future.
\end{abstract}

\section{Contents}

1. Introduction

2. Rho/ROCK pathway

3. The expression of Rho/ROCK in aqueous humor outflow pathways

4. Rho/ROCK pathway and the cytoskeletal integrity of cells in the outflow tissue

5. Rho/ROCK pathway and ECM in the outflow tissue

6. Rho/ROCK pathway and permeability of the SC endothelial cells

Correspondence to: Dr Yisheng Zhong, Department of Ophthalmology, Ruijin Hospital, Shanghai Jiao Tong University School of Medicine, 197 Rui Jin Er Road, Shanghai 200025, P.R. China

E-mail: yszhong68@126.com

*Contributed equally

Key words: Rho/Rho-associated kinase pathway, glaucoma, intraocular pressure, anti-scarring effect, neuroprotection
7. Rho/ROCK pathway and IOP modulation

8. Rho/ROCK pathway and wound healing of filtration canal

9. Rho/ROCK pathway and optic nerve neuroprotection

10. Conclusion

\section{Introduction}

Glaucoma is a leading cause of permanent blindness and is characterized by progressive retinal ganglion cell (RGC) death that produces characteristic optic nerve head damage and visual field loss $(1,2)$. Some risk factors are related with glaucoma pathogenesis. These include intraocular pressure (IOP), age, family history, clinical appearance of the optic nerve, race and potential vascular disease (3-6). Of these, elevated IOP is considered as a major risk factor for glaucoma, and lowering IOP is the most effective treatment method available for glaucoma $(1,2)$.

Several prospective randomized multi-center studies have identified that IOP reduction with either medicines or surgery can reduce the development and progression of vision loss in glaucoma patients (7-13). The precise mechanisms that lead to the death of RGCs in glaucoma have not been identified conclusively, but might involve the blockade of both anterograde and retrograde axonal transport leading to the deprivation of neurotrophic signals (2). If IOP is beyond the tolerable range of the optic nerve, RGCs axons degenerate at the optic nerve head in the region of the lamina cribrosa, a process that occurs in parallel to the apoptotic death of RGCs. The glaucomatous neuropathy might occur in parallel to a remodeling of the extracellular matrix (ECM) of the optic nerve head $(2,14,15)$.

IOP is determined by the equilibrium between the secretion of aqueous humor by the ciliary body and the drainage of aqueous humor from the eye. There are two main aqueous humor outflow pathways, trabecular (conventional) and uveoscleral (unconventional). The unconventional route of this drainage is through the interstitial spaces of the ciliary muscle and the supraciliary space, whose physiological role is not fully understood. The conventional outflow pathway is composed of the trabecular meshwork (TM), juxtacanalicular tissue (JCT), Schlemm's canal (SC), and the episcleral veins on a continuous basis, and in humans, this pathway represents a predominant route of aqueous humor drainage $(16,17)$. The ciliary secretion of aqueous humor usually remains normal in glaucoma (18), therefore, it is thought that impaired drainage through the trabecular pathway caused by increased resistance is the primary cause for increased IOP in primary open-angle glaucoma (POAG) (18). 
The normal aqueous humor outflow resistance resides in the inner wall region of the trabecular meshwork outflow pathways $(19,20)$. The site of highest resistance remains uncertain $(21,22)$, but likely resides at the confluence of the TM, JCT and SC inner wall $(21,23)$. It has been proposed that abnormal accumulation of extracellular material/ECM (ECM hypothesis), and changes in contractile activity and cell adhesive interactions of the cells of aqueous outflow pathway (contractility hypothesis) are contributed to increases resistance to drainage of aqueous humor through the conventional pathway (16-18,24-26). The ECM hypothesis is supported by the observation that perfusion of anterior eye segments in organ cultures with metalloproteinases that digest ECM components leads to a reversible increase in outflow facility (27). The contractility hypothesis is supported by the observation that experimental disruption of the actin cytoskeleton of the trabecular meshwork decreases outflow resistance $(28,29)$ and by recent findings which provide evidence that the trabecular meshwork of patients with primary open angle glaucoma is stiffer than that of age-matched controls (30). The two hypotheses can exist simultaneously, since it is possible that trabecular meshwork cells that increase their contractile capabilities simultaneously synthesize more fibrillar matrix to transmit more force.

Over the past few years, many studies have shed light on the important role of Rho/Rho-associated kinase (ROCK) pathway in the pathogenesis and treatment of glaucoma. The purpose of this review is to summarize the role of Rho/ROCK pathway in the IOP modulation, subconjunctival scarring of the filtering bleb and neuroprotection of glaucoma.

\section{Rho/ROCK pathway}

Rho is a member of Rho family of small molecular guanosine triphosphatase (GTPase) superfamily related to Ras. Rho has three isomer types: RhoA, RhoB and RhoC (31). ROCK is a serine/threonine kinase and one of the major downstream effectors of Rho GTPases (32). ROCK has two isomer types: ROCK1 and ROCK2. The structures of ROCK1 and ROCK2 are conserved with $64 \%$ overall amino acid identity $(33,34)$. The kinase domain containing both extension segments is more highly conserved between these two proteins (83\% identical), suggesting that they may have similar substrate specificity $(33,34)$. Both Rho-kinase proteins are ubiquitously expressed in most tissues; however, higher levels of ROCK2 are found in brain and muscles whereas higher levels of ROCK1 are found in non-neuronal tissues including liver, lung and testis $(33,35)$. ROCK1 is specifically cleaved by caspase-3, whereas ROCK2 is cleaved by granzyme B (36-38). The Rho GTPases act as molecular switches by cycling between an active GTP-bound and an inactive GDP-bound form. In the GTP-bound form, the Rho GTPase interact with specific downstream effector proteins - ROCK, which include Rho kinase, regulators of actin polymerization and adaptor proteins (32). The activity of Rho GTPase is regulated by signaling input originating from different classes of cell surface receptors, including the heterotrimeric $\mathrm{G}$ protein-coupled receptors tyrosine kinase receptors, cytokine receptors, frizzled receptors, and adhesion receptors $(32,39)$. Rho/ROCK pathway has critical functions in the formation of actin stress fibers and focal adhesions (40-43), and the regulation of actomyosin cytoskeletal organization, cell adhesion, cell morphology, cell motility, smooth muscle contraction, neurite elongation and neuronal architecture and cytokinesis (44-55).

Rho/ROCK pathway is involved in various cellular functions through phosphorylation of their specific substrates. The main substrates of Rho/ROCK pathway is the myosin light chain (MLC), LIM kinase 1 (LIMK1), LIMK2 and myosin phosphatase target subunit 1 (MYPT1) (56-58). Gene silencing experiments suggest ROCK1 appears to be essential for the formation of stress fibers, whereas ROCK2 appears to be necessary for cytoskeletal rearrangements, cell motility and cell contraction, both of which are dependent on MLC phosphorylation $(59,60)$. The phosphorylation status of MLC is controlled not only by myosin light chain kinase (MLCK), but also by myosin light chain phosphatase (MLCP). MLC is phosphorylated by $\mathrm{Ca}^{2+} /$ calmodulin-dependent MLCK and dephosphorylated by $\mathrm{Ca}^{2+}$-independent MLCP, and the balance between these two enzyme activities is a critical determinant of MLC phosphorylation (61-63). Phosphorylation of MLC subsequently results in stimulation of the myosin-actin interactions. Increased and decreased MLC phosphorylation induces contraction and relaxation responses of the cell and influences the formation of actin stress fibers and smooth muscle contraction. ROCK is implicated in the RhoA-mediated inhibition of MLCP (64). Inhibition of ROCK results in an increased activity of MLCP and dephosphorylation of MLC. Thus, Rho/ROCK pathway is a master regulator of the actin cytoskeleton and cell contractility $(32,51,65,66)$. Growth factors, mechanical stretch, cytokines and ECM can activate Rho GTPase through guanine nucleotide exchange factors. This subsequently activates ROCK, which then leads to MLC phosphorylation that enhances actomyosin cross-bridging and contractility, thereby regulating many cell processes including contraction, cytoskeleton organization, adhesive interactions, trafficking and permeability $(48,51,65,67-70)$.

\section{The expression of Rho/ROCK in aqueous humor outflow pathways}

In vitro and in vivo studies have shown that Rho and ROCKs are expressed in the cells of outflow pathway $(53,71-74)$. Immunoblot analyses have shown that RhoA and ROCKs are present in cultured human TM cells (71-73), SC cells (73) and bovine ciliary muscle (CM) tissues (72). Using RT-PCR analysis, Nakajima and collaborators found ROCK1 and ROCK2 in TM and CM (53). Both in humans and in monkeys ROCKs were expressed in TM more abundantly than in CM (53). Goldhagen et al using immunohistochemical analysis found RhoA, ROCK1 and ROCK2 were all distributed in the human aqueous outflow pathway including TM, JCT and SC, and observed no significant difference in Rho/ROCK pathway expression in the outflow tissue between normal eyes and those with glaucoma (74). It is hypothesized that there would be increased expression of the Rho/ROCK pathway in the outflow tissue in glaucomatous eyes. However, the results of Goldhagen et al showed no significant expression difference of Rho/ Rho kinase between normal eyes and glaucomatous eyes (74), it can be explained that many medications used for the management of glaucoma may be affecting the expression of Rho/Rho kinase within the outflow pathway. 


\section{Rho/ROCK pathway and the cytoskeletal integrity of cells in the outflow tissue}

The TM beams have been characterized as connective tissue containing elastic and collagen fibers surrounded by endothelial-like trabecular cells resting on a basement membrane (16). The outermost JCT or cribriform region has no collagenous beams, but rather several cell layers immersed in a loose web of ECM fibrils. The adjacent SC is a continuous endothelium-lined channel that drains aqueous humor to the general venous circulation (29). The TM cells exhibit a smooth muscle-like phenotype, based on their expression of various smooth muscle-specific proteins, including $\alpha$-smooth muscle actin ( $\alpha$-SMA) and CPI-17 (the $17 \mathrm{kDa}$ protein kinase C-potentiated protein phosphatase 1 inhibitor protein) $(24,28,29,75,76)$. The actomyosin system, composed of actin microfilaments and associated proteins, is present in essentially all cells, and is highly organized in TM and SC cells. There are numerous microfilament-based structures in cells along the trabecular outflow pathway. These structures primarily include focal contacts, adherens cell-cell junctions and bundles of microfilaments (77). A physiologically contracted state of the JCT-SC region is required to maintain the microfilament-related structures in the outflow pathway (29). Microfilaments are involved in a variety of cellular processes from cell adhesion and motility to organelle traffic to adhesion-mediated signal transduction. As discussed above, ROCK mainly promotes myosin II activity by inhibiting MLCP as well as by phosphorylating the myosin regulatory light chain. This, in turn, induces the assembly of contractile actomyosin bundles that generate strong tensile forces (65). A specific Rho kinase inhibitor, Y-27632, induces reversible changes in cell shape and decreases in actin stress fibers, focal adhesions, and protein phosphotyrosine staining in human TM cells and SC cells $(72,73)$. In isolated bovine TM strips, Y-27632 completely blocks $\mathrm{Ca}^{2+}$-independent phorbol myristate acetate or endothelin-1-induced contraction $(71,78,79)$. A morphological study in bovine eyes indicates that, with Y-27632, the inner wall of SC and the JCT are significantly distended compared to control eyes, with discernible separation between the inner wall of SC and JCT, which suggests that the structural correlate to the increase in outflow facility of non-human eyes after Y-27632 is physical separation between the JCT and inner wall of SC (80).

Regulation of mechanical and contractile properties of the pressure-sensitive TM cells is recognized to play a significant role in modulation of aqueous humor outflow and ocular pressure homeostasis $(20,24,81-83)$. There is growing evidence, that contraction of TM reduces aqueous humor outflow and thus enhances intraocular pressure, whereas relaxation exerts the opposite effect $(24,29,72,75,76,84)$. The activation of Rho/ROCK pathway could result in TM contraction, and the inhibition of this pathway would provoke relaxation of TM with subsequent increase in outflow facility $(53,72,73,82)$. As expected, ROCK inhibitors, such as Y-27632, Y-39983, HA-1077, H-1152, increase outflow facility and/or decrease IOP in animals (72,85-88). Conversely, agents that activate Rho GTPase and myosin II activity, including lysophosphatidic acid (LPA), sphingosine-1-phosphate, TGF- $\beta 2$, and endothelin-1, decrease aqueous humor outflow facility concomitant with increased contractile activity of the TM cells, indicating a potential importance of actomyosin organization and the contractile force generated by the actomyosin system in the regulation of aqueous humor drainage (76,84,89-91). In addition to the effect on the contractility of cells in trabecular (conventional) outflow, Rho/ROCK pathway may also modulate the contractility of tissues in uveoscleral (unconventional) outflow $(72,92)$. CM is one of the main tissues in the uveoscleral outflow pathway, and CM cells morphologically and electrophysiologically express properties that are typical of smooth muscle cells (93). The ROCK inhibitor Y-27632 has been shown to induce inhibition of smooth muscle contraction and alter various cellular behavior (94,95). Moreover, Y-27632 can relax the excised ciliary muscle which is previously constricted by carbachol, suggesting that the inhibitor acts to increase the uveoscleral outflow (92). However, there is also evidence to the contrary. ROCK and its substrates show higher expression in TM compared to CM (53), and ROCK inhibitor Y-39983 leads to relaxation of TM, but Y-39983 is only slightly effective in CM (86). Honjo et al also reported that only a modest increase in the uveoscleral outflow was found in rabbit eyes by Y-27632, and its effects were not statistically significant (72). These results suggest that the mechanism for decreased IOP by ROCK inhibitor is largely mediated by enhancement of aqueous outflow facility through relaxation of TM in the conventional outflow pathway (24).

\section{Rho/ROCK pathway and ECM in the outflow tissue}

Alterations in ECM content and organization have been found to be associated with increased resistance in the outflow pathway of human glaucomatous eyes (96-100). Rho/ROCK pathway has an important role for modulating the synthesis of ECM components in the trabecular pathway. Pattabiraman and Rao found that human TM cells expressing a constitutively activated form of RhoA (RhoAV14) demonstrated increased levels of fibronectin, fibronectin fibril formation, laminin, tenascin $\mathrm{C}$ and $\alpha$-SMA (101). Furthermore, the changes in expression of ECM proteins could be suppressed by the Rho GTPase inhibitor (C3 transferase) and ROCK inhibitor (Y-27632), in association with decreased MLC phosphorylation, actin stress fibers, focal adhesions and fibronectin fibrils (101). Zhang et al reported that TM cells expressing a constitutively activated form of RhoA had increased expression of various ECM-related genes and cytokines such as TGF- $\beta$, interleukin-1, and connective tissue growth factor (CTGF) in TM cells (91). The stimulation of TM cells with physiological agonists such as LPA and TGF- $\beta 2$, which are known to induce Rho GTPase activation and MLC phosphorylation in TM $(90,102)$, leads to an increase in levels of fibronectin, fibronectin fibrils, laminin and $\alpha$-SMA in a RhoA- and Rho kinase-dependent manner. In the case of TGF- $\beta 2$, increased resistance to aqueous humor outflow is reported to be associated with increased levels of synthesis of ECM components $(25,98,103)$. CTGF has also an important role in ECM synthesis, Iyer et al reported that stimulation of human TM cells with CTGF treatment for $24 \mathrm{~h}$ led to an increase in the levels of laminin, fibronectin, and in the levels of phosphorylated MLC in human TM cells, and that the expression of CTGF is regulated closely by Rho GTPase (104). 
There is a potential interplay among the contractile activity, ECM synthesis and Rho GTPase activation (105-109). As mentioned above, the activation of Rho GTPase and ROCK was able to promote myosin II phosphorylation and contractile activity $(53,72,73,82)$, and to induce ECM synthesis/assembly in TM cells $(91,101,104)$. On the other hand, the actomyosinderived contractile force induced ECM synthesis/assembly and, conversely, ECM assembly/rigidity could influence actomyosin contraction and induce Rho GTPase activation (91). ECM rigidity has been reported to increase fibronectin fibril formation, Erk activation, focal adhesion kinase activity, $\alpha$-SMA, and actin stress fibers in TM cells (110). The interplay among contractile activity, ECM synthesis/assembly and Rho GTPase activation in the cells of aqueous humor outflow pathway, including TM, JCT and SC cells, represents a crucial regulatory component in the homeostasis of aqueous humor outflow resistance (101).

\section{Rho/ROCK pathway and permeability of the SC endothelial cells}

The permeability of SC endothelial cells is suggested to play important roles in the regulation of aqueous outflow $(17,111)$. Breaks have been found in the endothelial lining of the SC and aqueous plexus after perfusion with certain cytoskeletal drugs (112-114). Additionally, SC endothelial cells have transcellular pores accompanied by giant vacuoles $(111,115)$. ROCK inhibitor Y-27632 resulted in Rho/ROCK-dependent filamentous actin reorganization and disruption of proteins associated with tight junction, increased SC endothelial-cell monolayer permeability, which may lead to increased aqueous humor outflow facility $(73,111)$.

\section{Rho/ROCK pathway and IOP modulation}

Rho/ROCK pathway has a crucial role in IOP modulation. In general, the activation of Rho/ROCK pathway in the outflow tissue results in reduction of aqueous humor outflow, and thereby increase IOP, whereas the inhibition of Rho/ ROCK pathway tissue results in increase of aqueous humor outflow, and thereby decrease IOP. Organ-cultured anterior segments from porcine eyes expressing RhoAV14 exhibited significant reduction of aqueous humor outflow (91). However, inhibiting RhoA expression in TM with siRNA is effective in suppressing elevated IOP in mice (116). Furthermore, several ROCK inhibitors, such as Y-27632, Y-39983, HA-1077 and $\mathrm{H}-1152$, increase outflow facility and/or decrease IOP in living rabbits, mouse, rat, monkeys, human and enucleated porcine eyes $(72,73,76,85-88,92,117-120)$. In monkey eyes, $0.05 \%$ Y-39983 induces significant IOP reduction almost equal to that obtained with $0.005 \%$ latanoprost (86). SNJ-1656, an ophthalmic solution of Y-39983, has been proved as a safe topical agent that is effective in reducing IOP in healthy adult volunteers (87). Thus, ROCK inhibitors might be a candidate for the next generation of glaucoma therapy $(53,119)$.

\section{Rho/ROCK pathway and wound healing of filtration canal}

Filtration surgery, such as trabeculectomy, is the most widely used anti-glaucoma surgery. The most frequent cause of failure of glaucoma filtration surgery is postoperative scarring in the filtering bleb. Fibroblasts from the subconjunctival space play a key role in the scarring process. Perioperative administration of antimetabolites such as 5-fluorouracil and mitomycin C (MMC) is effective in limiting the scarring process. However, use of these antiproliferative agents is accompanied by severe side-effects $(121,122)$. Therefore, alternative anti-scarring agents that do not cause extensive tissue damage are needed.

Subconjunctival scarring of the filtering bleb site is mainly mediated by tenon fibroblasts (TFs) proliferation, migration, and contraction (123-125). Transdifferentiation of fibroblasts into myofibroblasts is a crucial step in wound healing and scar formation (126), which is associated with expression of $\alpha$-SMA (127). Enhanced $\alpha$-SMA expression indicates the presence of activated fibroblasts with increased synthesis of ECM proteins, growth factors and integrins $(128,129)$. Myofibroblasts are responsible for fibrosis via increased ECM synthesis, for granulation tissue formation, wound contraction and scar formation (126,130-132). TFs are stimulated by growth factors to differentiate into myofibroblasts both in vitro (133), and in vivo (134). LPA and serum, as well as TGF- $\beta$, could activate myofibroblast differentiation (135-138), which is supposedly one of the most potent stimulators of TFs (124). After glaucoma filtration surgery, TFs are likely to be exposed to LPA via serum and/or plasma, because the blood-aqueous humor barrier breaks down, and circulating aqueous humor bathes the wound site (139).

ROCK inhibitors can inhibit cell migration, invasion (140) and cytokinesis $(141,142)$, all of which have a role in wound healing and scar formation, therefore, the Rho/ROCK pathway has critical functions in regulation of wound healing of filtration canal. ROCK inhibitors (Y-27632, HA-1077 and H-1152) have been reported to reduce or block LPA-induced and TGF- $\beta$-induced $\alpha$-SMA expression in TFs $(133,143-146)$, which suggests that ROCK inhibitors serve as a potent anti-scarring agent via inhibition of transdifferentiation of TFs into myofibroblasts (146). Meyer-ter-Vehn et al found that ROCK inhibitors did not alter the Smad2 phosphorylation pattern, but inhibited TGF- $\beta$-induced phosphorylation of p38 in TFs (133). Honjo et al (146) reported that Y-27632 induced profound changes in cultured human TFs without significant toxicity or inhibition of human TFs proliferation. In addition, topical instillation of Y-27632 was effective in preventing fibroproliferation and scar formation in a rabbit model of glaucoma surgery (146). Therefore, the ROCK inhibitors have potential to be anti-scarring agents after glaucoma filtering surgery.

\section{Rho/ROCK pathway and optic nerve neuroprotection}

Normal human optic nerve head (ONH) express RhoA, ROCK1 and ROCK2 (74). The cultured glaucomatous ONH astrocytes exhibit upregulated expression of Rho GTPase and certain ECM proteins (147), and the RhoA expression in the $\mathrm{ONH}$ of human glaucoma eyes is increased significantly when compared with age-matched normal subjects, indicating a possible involvement of RhoA/ROCK pathway in the pathophysiology of the optic nerve damage from glaucoma (74). 
Increase in ocular blood flow. The Rho/ROCK pathway is expressed in vascular smooth muscles (148-151), and ROCK inhibitors have been known to relax various vascular smooth muscles (152-156), which may enhance ocular and retinal blood flow by inducing vasodilatation and, thus, provide neuroprotective action. Cell culture experiments and studies using isolated vessel preparations demonstrated that the constrictor effects of endothelin and angiotensin II and the generation of myogenic tone are mainly mediated by ROCK activation (157-160), thus the inhibition of ROCK activation could eliminate the vessel contraction induced by endothelin and angiotensin II. The experiment in vitro showed that selective ROCK inhibitors (Y-27632 and Y-39983) induced concentration-dependent relaxation of isolated rabbit ciliary arteries (161), and demonstrated that the mechanism of relaxation may decrease the $\mathrm{Ca}^{2+}$ sensitivity of key intracellular contractile protein(s) and/or alter regulation of Rho kinases (161). The studies in vivo also demonstrated that topical application of ROCK inhibitor (Y-27632, Y-39983 and fasudil) increased ONH blood flow in rabbit (161-163). Okamura et al reported that systemic administration of fasudil had vasodilator effects on retinal arterioles in strokeprone spontaneously hypertensive rats (164). Sugiyama et al also found that systemic or topical fasudil suppressed impairment of ONH blood flow, function and morphology induced by NG-nitro-L-arginine methyl ester (L-NAME) or endothelin-1 (163), and the amelioration could be inhibited by a specific inhibitor of Akt/PI-3 kinase, which suggests that these actions of fasudil might be caused by inhibition of ROCK, leading to phosphorylation and activation of Akt via the PI-3 kinase (165). Decreased perfusion is thought to be one of the causative factors in loss of vision in glaucoma (166-169), ROCK inhibitors could increase blood flow velocity in optic nerve head, which suggests that Rho/ROCK signaling may be a promising target for the treatment of glaucoma optic neuropathy.

Improved RGC survival. There is increasing evidence demonstrating the protective effects of RhoA/ROCKinhibition on adult retinas. The intraocular injection of the RhoA antagonist C3 is reported to increase both axonal regeneration and RGC survival after optic nerve axotomy in rats (170). The inhibition of ROCK (fasudil) was shown to decrease the extent of N-methyl-D-aspartic acid (NMDA)induced neurotoxicity in rat retinas (171). In an in vivo rat model of glaucoma, intraperitoneal injection of the Rho kinase inhibitor fasudil protected against neuronal loss $(172,173)$, which suggested that abnormal activity of Rho/ Rho kinase pathway may participate in the pathophysiology of glaucoma (82). Inactivation of Rho/ROCK signaling also contributes to the neuroprotectivity of neuronal cells in the retinal ischemia/reperfusion injury. Retinal ischemia/reperfusion injury leads to a loss of neuronal cells in the inner retinal layers such as RGCs and amacrine cells $(174,175)$, and neuronal cell apoptosis induced by transient retinal ischemia progresses through the reperfusion phase rather than the ischemic phase. Injury during reperfusion is caused by the infiltration of leukocytes into the neural tissue through vascular endothelial cells (176). The Rho/Rho kinase pathway contributes to leukocyte extravasation by regulating the leukocyte cytoskeleton and tight junction of endothelial cells $(177,178)$. ROCK inhibitors attenuate the ischemia/reperfusion induced apoptosis of retinal cells in the inner retinal layers (including RGCs) by decreasing $\mathrm{Bax} / \mathrm{Bcl}-2$ mRNA ratio and the expression of caspase-3 and iNOS (179), and by regulating leukocyte infiltration in the neural tissue $(180,181)$. The treatment with the ROCK inhibitor Y-27632 could promote the viability of primary RGCs, the RGCs-5 cell line (182). Moreover, ROCK inhibition also rescues RGCs from axotomy-induced apoptosis in vivo, and the neuroprotective effects of the ROCK inhibitor Y-27632 are mediated by the activation of well-established cell survival pathways, such as the Akt and MAPK pathways (182). Furthermore, Tura et al found that the neuroprotective effect of $\mathrm{H}-1152 \mathrm{P}$ on retinal cells, particularly in RGCs, was associated with a decrease in the reactivity of astrocytes, Müller cells, and microglia both in retinas cultured under serum deprivation and after optic nerve crush, which suggested the neuroprotective effect of H-1152P-mediated ROCK-inhibition on retinal cells under stress may rely partly on the attenuation of glial cell reactivity (183).

Promotion of $R G C$ axon regeneration. The failure of axon regeneration after injury to the mammalian CNS is attributable to the limited availability of neurotrophic factors (NTF) which promote neuron survival and axon regeneration, and the presence of myelin- and scar-derived inhibitory molecules such as Nogo-A, myelin associated glycoprotein (MAG), oligodendrocyte-myelin glycoprotein (Omgp), chondroitin sulphate proteoglycan (CSPG), ephrins and semaphorins (184-191). After binding to their cognate receptors, these inhibitory molecules converge on the Rho/ROCK pathway to change actin dynamics and initiate growth cone collapse $(184,186,187,192)$. The Rho/ROCK pathway has been mainly associated with inhibitory signaling for neurite elongation (193), and inactivation of Rho/ROCK pathway can promote the regeneration (193). As discussed above, ONH expresses RhoA, ROCK1 and ROCK2 (74), and their presence in the optic nerve suggests a potential role for the Rho/ROCK pathway in neurite outgrowth and axon regeneration through actin cytoskeletal reorganization (147). Inhibition of Rho and ROCK has been shown to increase RGC axon regeneration $(193,194)$. It has been shown that intraocular delivery of C3-exoenzyme, an inactivator of Rho GTPase, can promote the regeneration of $\mathrm{RGC}$ axons in the optic nerve after a microcrush lesion $(193,195)$. On the other hand, ROCK inhibitors have also been shown to increase regeneration in different optic nerve lesion models (182,195-198). In terms of their intensity, the effect of Y-39983 in promotion of neurite outgrowth was stronger than that of Y-27632, fasudil and dimethylfasudil $(194,196)$. In addition to a ROCK inhibitor used alone, the treatment with ROCK inhibitor (Y-27632) in combination with CNTF and/or raised cAMP levels has additive effects, and promotes robust RGCs axon regeneration $(182,197)$. We recently found that RhoA/ROCK signaling pathway was involved in the erythropoietin (EPO) effect to promote RGC axon regeneration after optic nerve crush, and EPO and Y-27632 had additive effects in promoting RGC axon regeneration (199). 


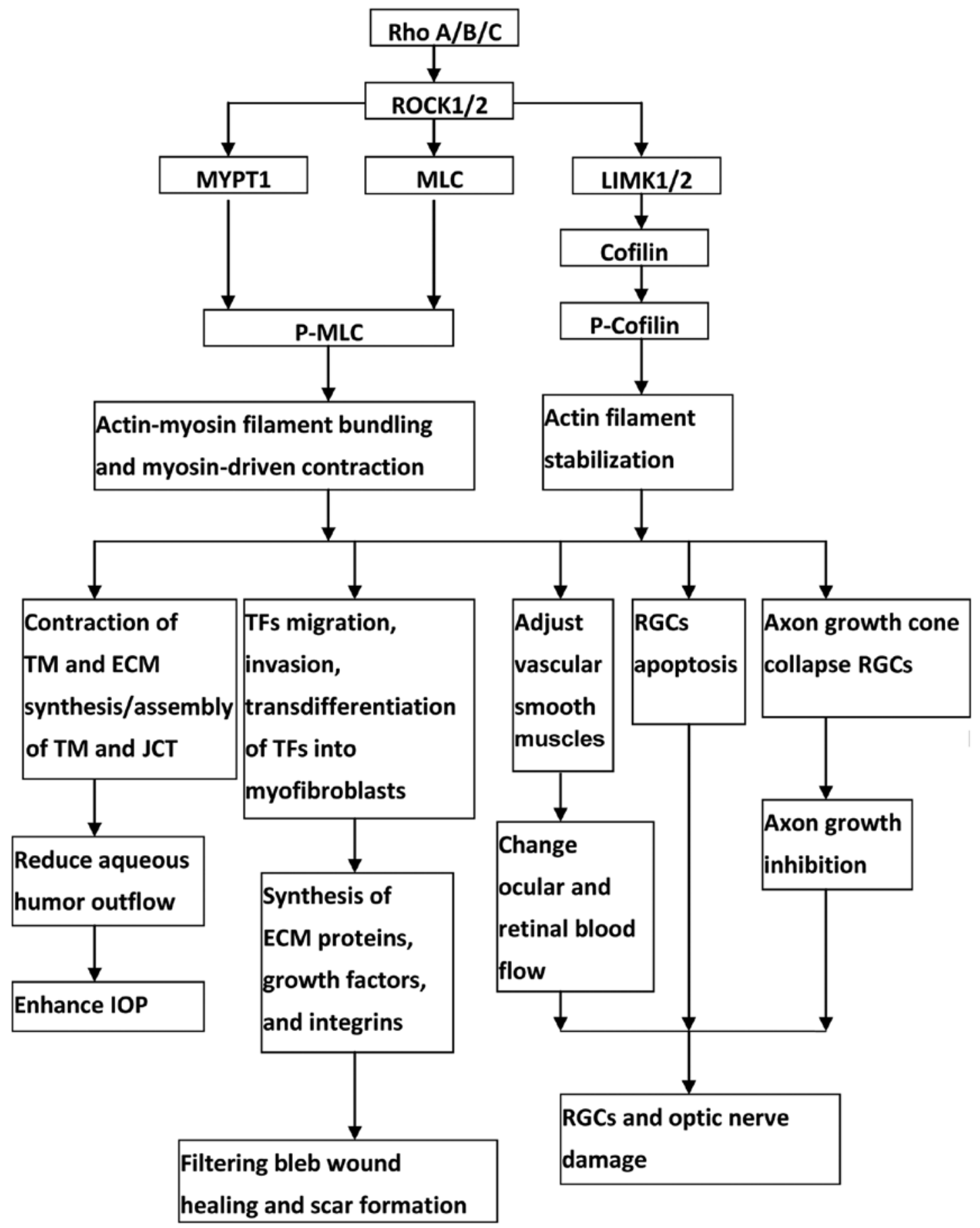

Figure 1. The diagram of Rho/ROCK effect on IOP, filtering bleb and optic nerve. ROCK, Rho/Rho-associated kinase; MYPT1, myosin phosphatase target subunit 1; MLC, myosin light chain; P-MLC, phosphorylation of MLC; LIMK1/2, LIM kinase1/2; P-Cofilin, phosphorylation of cofilin; TM, trabecular meshwork; ECM, extracellular matrix; JCT, juxtacanalicular tissue; TFs, Tenon fibroblasts; IOP, intraocular pressure; RGCs, retinal ganglion cells.

\section{Conclusion}

Rho/ROCK pathway has important roles for modulating the cytoskeletal integrity of cells, the synthesis of ECM components in the outflow tissue, and the permeability of the $\mathrm{SC}$ endothelial cells. The activation of Rho/ROCK pathway in the outflow tissue results in reduction of aqueous humor outflow, and thereby increase IOP, whereas the inhibition of Rho/ROCK pathway in the outflow tissue results in increase of aqueous humor outflow, and thereby decrease IOP. ROCK inhibitors also serve as a potent anti-scarring agent via inhibition of transdifferentiation of TFs into myofibroblasts. Furthermore, RhoA/ROCK pathway is involved in optic nerve neuroprotection. Inactivation of Rho/ROCK signaling could increase ocular blood flow, improve RGCs survival and promote RGCs axon regeneration. Considering the IOP modulation, potent bleb anti-scarring effect and neuroprotective properties of ROCK inhibitors (Fig. 1), Rho/ROCK pathway is an attractive target for anti-glaucoma therapy, and it may be used for human therapy in the near future. 


\section{Acknowledgements}

This study was funded by the National Natural Science Foundation of China (nos. 81070728, 81371014 and 81000373), Shanghai leading Academic Discipline Project (no. S30205) and Shanghai 'Science and Technology Innovation Action Plan' Basic Research Key Project (nos. 11JC1407700 and 11JC1407701).

\section{References}

1. Weinreb RN and Khaw PT: Primary open-angle glaucoma. Lancet 363: 1711-1720, 2004.

2. Quigley HA: Glaucoma. Lancet 377: 1367-1377, 2011.

3. Sommer A: Intraocular pressure and glaucoma. Am J Ophthalmol 107: 186-188, 1989.

4. Tielsch JM, Sommer A, Katz J, Royall RM, Quigley HA and Javitt J: Racial variations in the prevalence of primary openangle glaucoma. The Baltimore Eye Survey. JAMA 266 369-374, 1991.

5. Klein BE, Klein R, Sponsel WE, Franke T, Cantor LB, Martone J and Menage MJ: Prevalence of glaucoma. The Beaver Dam Eye Study. Ophthalmology 99: 1499-1504, 1992.

6. Mitchell P, Smith W, Attebo K and Healey PR: Prevalence of open-angle glaucoma in Australia. The Blue Mountains Eye Study. Ophthalmology 103: 1661-1669, 1996.

7. Collaborative Normal-Tension Glaucoma Study Group: Comparison of glaucomatous progression between untreated patients with normal-tension glaucoma and patients with therapeutically reduced intraocular pressures. Am J Ophthalmol 126: 487-497, 1998

8. Collaborative Normal-Tension Glaucoma Study Group: The effectiveness of intraocular pressure reduction in the treatment of normal-tension glaucoma. Am J Ophthalmol 126: 498-505, 1998.

9. The AGIS Investigators: The advanced glaucoma intervention study (AGIS): 7. The relationship between control of intraocular pressure and visual field deterioration. Am J Ophthalmol 130: 429-440, 2000

10. Lichter PR, Musch DC, Gillespie BW, Guire KE, Janz NK, Wren PA and Mills RP: Interim clinical outcomes in the Collaborative Initial Glaucoma Treatment Study comparing initial treatment randomized to medications or surgery. Ophthalmology 108: 1943-1953, 2001.

11. Gordon MO, Beiser JA, Brandt JD, Heuer DK, Higginbotham EJ, Johnson CA, Keltner JL, Miller JP, Parrish RK II, Wilson MR and Kass MA: The Ocular Hypertension Treatment Study: baseline factors that predict the onset of primary open-angle glaucoma. Arch Ophthalmol 120: 714-720, 2002.

12. Kass MA, Heuer DK, Higginbotham EJ, Johnson CA, Keltner JL, Miller JP, Parrish RK 2nd, Wilson MR and Gordon MO: The Ocular Hypertension Treatment Study: a randomized trial determines that topical ocular hypotensive medication delays or prevents the onset of primary open-angle glaucoma. Arch Ophthalmol 120: 701-713, 2002.

13. Leske MC, Heijl A, Hussein M, Bengtsson B, Hyman L and Komaroff E: Factors for glaucoma progression and the effect of treatment: the early manifest glaucoma trial. Arch Ophthalmol 121: 48-56, 2003.

14. Hernandez MR: The optic nerve head in glaucoma: role of astrocytes in tissue remodeling. Prog Retin Eye Res 19: 297-321, 2000.

15. Burgoyne CF: A biomechanical paradigm for axonal insult within the optic nerve head in aging and glaucoma. Exp Eye Res 93: 120-132, 2011.

16. Lutjen-Drecoll E: Functional morphology of the trabecular meshwork in primate eyes. Prog Retin Eye Res 18: 91-119, 1999.

17. Tan JC, Peters DM and Kaufman PL: Recent developments in understanding the pathophysiology of elevated intraocular pressure. Curr Opin Ophthalmol 17: 168-174, 2006.

18. Gabelt BT and Kaufman PL: Changes in aqueous humor dynamics with age and glaucoma. Prog Retin Eye Res 24: 612-637, 2005

19. Grant WM: Experimental aqueous perfusion in enucleated human eyes. Arch Ophthalmol 69: 783-801, 1963.

20. Johnson M: What controls aqueous humour outflow resistance? Exp Eye Res 82: 545-557, 2006.
21. Tamm ER: The trabecular meshwork outflow pathways: Structural and functional aspects. Exp Eye Res 88: 648-655, 2009.

22. Kumar J and Epstein DL: Rho GTPase-mediated cytoskeletal organization in Schlemm's canal cells play a critical role in the regulation of aqueous humor outflow facility. J Cell Biochem 112: 600-606, 2011.

23. Ethier CR: The inner wall of Schlemm's canal. Exp Eye Res 74: 161-172, 2002.

24. Wiederholt M, Thieme $\mathrm{H}$ and Stumpff F: The regulation of trabecular meshwork and ciliary muscle contractility. Prog Retin Eye Res 19: 271-295, 2000.

25. Lutjen-Drecoll E: Morphological changes in glaucomatous eyes and the role of TGF $\beta 2$ for the pathogenesis of the disease. Exp Eye Res 81: 1-4, 2005.

26. Fuchshofer R and Tamm ER: The role of TGF- $\beta$ in the pathogenesis of primary open-angle glaucoma. Cell Tissue Res 347: 279-290, 2012.

27. Bradley JM, Vranka J, Colvis CM, Conger DM, Alexander JP, Fisk AS, Samples JR and Acott TS: Effect of matrix metalloproteinases activity on outflow in perfused human organ culture. Invest Ophthalmol Vis Sci 39: 2649-2658, 1998.

28. Tian B, Geiger B, Epstein DL and Kaufman PL: Cytoskeletal involvement in the regulation of aqueous humor outflow. Invest Ophthalmol Vis Sci 41: 619-623, 2000.

29. Tian B, Gabelt BT, Geiger B and Kaufman PL: The role of the actomyosin system in regulating trabecular fluid outflow. Exp Eye Res 88: 713-717, 2009.

30. Last JA, Pan T, Ding Y, Reilly CM, Keller K, Acott TS, Fautsch MP, Murphy CJ and Russell P: Elastic modulus determination of normal and glaucomatous human trabecular meshwork. Invest Ophthalmol Vis Sci 52: 2147-2152, 2011.

31. Erschbamer MK, Hofstetter CP and Olson L: RhoA, RhoB, RhoC, Rac1, Cdc42, and Tc10 mRNA levels in spinal cord, sensory ganglia, and corticospinal tract neurons and longlasting specific changes following spinal cord injury. J Comp Neurol 484: 224-233, 2005.

32. Etienne-Manneville $S$ and Hall A: Rho GTPases in cell biology. Nature 420: 629-635, 2002.

33. Nakagawa O, Fujisawa K, Ishizaki T, Saito Y, Nakao K and Narumiya S: ROCK-I and ROCK-II, two isoforms of Rho-associated coiled-coil forming protein serine/threonine kinase in mice. FEBS Lett 392: 189-193, 1996.

34. Riento K and Ridley AJ: Rocks: multifunctional kinases in cell behaviour. Nat Rev Mol Cell Biol 4: 446-456, 2003.

35. Leung T, Chen XQ, Manser E and Lim L: The p160 RhoA-binding kinase ROK alpha is a member of a kinase family and is involved in the reorganization of the cytoskeleton. Mol Cell Biol 16: 5313-5327, 1996.

36. Coleman ML, Sahai EA, Yeo M, Bosch M, Dewar A and Olson MF: Membrane blebbing during apoptosis results from caspase-mediated activation of ROCK I. Nat Cell Biol 3: 339-345, 2001.

37. Sebbagh M, Renvoizé C, Hamelin J, Riché N, Bertoglio J and Bréard J: Caspase-3-mediated cleavage of ROCK I induces MLC phosphorylation and apoptotic membrane blebbing. Nat Cell Biol 3: 346-352, 2001

38. Sebbagh M, Hamelin J, Bertoglio J, Solary E and Bréard J: Direct cleavage of ROCK II by granzyme B induces target cell membrane blebbing in a caspase-independent manner. J Exp Med 201: 465-471, 2005

39. Van Aelst L and D'Souza-Schorey C: Rho GTPases and signaling networks. Genes Dev 11: 2295-2322, 1997.

40. Ridley AJ, Paterson HF, Johnston CL, Diekmann D and Hall A: The small GTP-binding protein rho regulates growth factorinduced membrane ruffling. Cell 70: 401-410, 1992.

41. Ridley AJ and Hall A: Signal transduction pathways regulating Rho-mediated stress fibre formation: requirement for a tyrosine kinase. EMBO J 13: 2600-2610, 1994.

42. Nobes $\mathrm{C}$ and Hall A: Regulation and function of the Rho subfamily of small GTPases. Curr Opin Genet Dev 4: 77-81, 1994

43. Takai Y, Sasaki T, Tanaka K and Nakanishi H: Rho as a regulator of the cytoskeleton. Trends Biochem Sci 20: 227-231, 1995.

44. Paterson HF, Self AJ, Garrett, MD Just I, Aktories K and Hall A: Microinjection of recombinant p21rho induces rapid changes in cell morphology. J Cell Biol 111: 1001-1007, 1990.

45. Hirata K, Kikuchi A, Sasaki T, Kuroda S, Kaibuchi K, Matsuura Y, Seki H, Saida K and Takai Y: Involvement of rho p21 in the GTP-enhanced calcium ion sensitivity of smooth muscle contraction. J Biol Chem 267: 8719-8722, 1992. 
46. Narumiya S: The small GTPase Rho: cellular functions and signal transduction. J Biochem (Tokyo) 120: 215-228, 1996.

47. Gong MC, Iizuka K, Nixon G, Browne JP, Hall A, Eccleston JF, Sugai M, Kobayashi S, Somlyo AV and Somlyo AP: Role of guanine nucleotide-binding proteins - ras-family or trimeric proteins or both - in $\mathrm{Ca}^{2+}$ sensitization of smooth muscle. Proc Natl Acad Sci USA 93: 1340-1345, 1996.

48. Narumiya $S$, Ishizaki $\mathrm{T}$ and Watanabe N: Rho effectors and reorganization of actin cytoskeleton. FEBS Lett 410: 68-72, 1997.

49. Kaibuchi K, Kuroda S and Amano M: Regulation of the cytoskeleton and cell adhesion by the Rho family GTPases in mammalian cells. Annu Rev Biochem 68: 459-486, 1999.

50. Somlyo AP and Somlyo AV: Signal transduction by G-proteins, rho-kinase and protein phosphatase to smooth muscle and nonmuscle myosin II. J Physiol 522: 177-185, 2000.

51. Fukata Y, Amano M and Kaibuchi K: Rho-Rho-kinase pathway in smooth muscle contraction and cytoskeletal reorganization of non-muscle cells. Trends Pharmacol Sci 22: 32-39, 2001.

52. Nakayama M, Amano M, Katsumi A, Kaneko T, Kawabata S, Takefuji M and Kaibuchi K: Rho-kinase and myosin II activities are required for cell type and environment specific migration. Genes Cells 10: 107-117, 2005.

53. Nakajima E, Nakajima T, Minagawa Y, Shearer TR and Azuma M: Contribution of ROCK in contraction of trabecular meshwork: proposed mechanism for regulating aqueous outflow in monkey and human eyes. J Pharm Sci 94: 701-708, 2005.

54. Amano M, Nakayama $M$ and Kaibuchi K: Rho-kinase/ ROCK: A key regulator of the cytoskeleton and cell polarity. Cytoskeleton (Hoboken) 67: 545-554, 2010.

55. Tan HB, Zhong YS, Cheng Y and Shen X: Rho/ROCK pathway and neural regeneration: a potential therapeutic target for central nervous system and optic nerve damage. Int J Ophthalmol 4: 652-657, 2011

56. Asano T, Ikegaki I, Satoh S, Suzuki Y, Shibuya M, Takayasu M and Hidaka H: Mechanism of action of a novel antivasospasm drug, HA1077. J Pharmacol Exp Ther 241: 1033-1040, 1987.

57. Asano T, Suzuki T, Tsuchiya M, Satoh S, Ikegaki I, Shibuya M Suzuki Y and Hidaka H: Vasodilator actions of HA1077 in vitro and in vivo putatively mediated by the inhibition of protein kinase. Br J Pharmacol 98: 1091-1100, 1989.

58. Honjo M, Inatani M, Kido N, Sawamura T, Yue BY, Honda Y and Tanihara H: A myosin light chain kinase inhibitor, ML-9, lowers the intraocular pressure in rabbit eyes. Exp Eye Res 75 : 135-142, 2002.

59. Yoneda A, Multhaupt HA and Couchman JR: The Rho kinases I and II regulate different aspects of myosin II activity. J Cell Biol 170: 443-453, 2005

60. Wang Y, Zheng XR, Riddick N, Bryden M, Baur W, Zhang X and Surks HK: ROCK isoform regulation of myosin phosphatase and contractility in vascular smooth muscle cells. Circ Res 104: 531-540, 2009.

61. Hartshorne DJ: Myosin phosphatase: subunits and interactions. Acta Physiol Scand 164: 483-493, 1998.

62. Pfitzer G: Invited review: regulation of myosin phosphorylation in smooth muscle. J Appl Physiol 91: 497-503, 2001.

63. Harnett KM and Biancani P: Calcium-dependent and calciumindependent contractions in smooth muscles. Am J Med 115 (Suppl 3A): 24S-30S, 2003.

64. Kimura K, Ito M, Amano M, Chihara K, Fukata Y, Nakafuku M Yamamori B, Feng J, Nakano T, Okawa K, Iwamatsu A and Kaibuchi K: Regulation of myosin phosphatase by rho and rho-associated kinase (rho-kinase). Science 273: 245-248, 1996.

65. Wettschureck N and Offermanns S: Rho/Rho-kinase mediated signaling in physiology and pathophysiology. J Mol Med 80: 629-638, 2002

66. Somlyo AP and Somlyo AV: $\mathrm{Ca}^{2+}$ sensitivity of smooth muscle and nonmuscle myosin II: modulated by $\mathrm{G}$ proteins, kinases, and myosin phosphatase. Physiol Rev 83: 1325-1358, 2003.

67. Hall A: Rho GTPases and the actin cytoskeleton. Science 279 509-514, 1998

68. Ridley AJ: Rho GTPases and cell migration. J Cell Sci 114: 2713-2722, 2001

69. Jaffe AB and Hall A: Rho GTPases: biochemistry and biology. Annu Rev Cell Dev Biol 21: 247-269, 2005.

70. Spindler V, Schlegel N and Waschke J: Role of GTPases in control of microvascular permeability. Cardiovasc Res 87 $243-253,2010$

71. Thieme H, Nuskovski M, Nass JU, Pleyer U, Strauss O and Wiederholt M: Mediation of calcium-independent contraction in trabecular meshwork through protein kinase $\mathrm{c}$ and rho-A. Invest Ophthalmol Vis Sci 41: 4240-4246, 2000.
72. Honjo M, Tanihara H, Inatani M, Kido N, Sawamura T, Yue BY, Narumiya S and Honda Y: Effects of rho-associated protein kinase inhibitor Y-27632 on intraocular pressure and outflow facility. Invest Ophthalmol Vis Sci 42: 137-144, 2001

73. Rao PV, Deng PF, Kumar J and Epstein DL: Modulation of aqueous humor outflow facility by the Rho kinase-specific inhibitor Y-27632. Invest Ophthalmol Vis Sci 42: 1029-1037, 2001.

74. Goldhagen B, Proia AD, Epstein DL and Rao PV: Elevated levels of RhoA in the optic nerve head of human eyes with glaucoma. J Glaucoma 21: 530-538, 2012.

75. Epstein DL, Rowlette LL and Roberts BC: Acto-myosin drug effects and aqueous outflow function. Invest Ophthalmol Vis Sci 40: 74-81, 1999

76. Rao PV, Deng P, Sasaki Y and Epstein DL: Regulation of myosin light chain phosphorylation in the trabecular meshwork: role in aqueous humour outflow facility. Exp Eye Res 80: 197-206, 2005.

77. Geiger B, Yehuda-Levenberg S and Bershadsky AD: Molecular interactions in the submembrane plaque of cell-cell and cell-matrix adhesions. Acta Anat (Basel) 154: 46-62, 1995.

78. Rosenthal R, Choritz L, Schlott S, Bechrakis NE, Jaroszewski J, Wiederholt $\mathrm{M}$ and Thieme H: Effects of ML-7 and Y-27632 on carbachol- and endothelin-1-induced contraction of bovine trabecular meshwork. Exp Eye Res 80: 837-845, 2005.

79. Renieri G, Choritz L, Rosenthal R, Meissner S, Pfeiffer N and Thieme H: Effects of endothelin-1 on calcium-independent contraction of bovine trabecular meshwork. Graefes Arch Clin Exp Ophthalmol 246: 1107-1115, 2008.

80. Lu Z, Overby DR, Scott PA, Freddo TF and Gong H: The mechanism of increasing outflow facility by rho-kinase inhibition with Y-27632 in bovine eyes. Exp Eye Res 86: 271-281, 2008.

81. Johnstone MA: The aqueous outflow system as a mechanical pump: evidence from examination of tissue and aqueous movement in human and non-human primates. J Glaucoma 13: 421-438, 2004.

82. Rao VP and Epstein DL: Rho GTPase/Rho kinase inhibition as a novel target for the treatment of glaucoma. BioDrugs 21: $167-177,2007$.

83. WuDunn D: Mechanobiology of trabecular meshwork cells Exp Eye Res 88: 718-723, 2009.

84. Wiederholt M, Bielka S, Schweig F, Lutjen-Drecoll E and Lepple-Wienhues A: Regulation of outflow rate and resistance in the perfused anterior segment of the bovine eye. Exp Eye Res 61: 223-234, 1995

85. Honjo M, Inatani, M Kido N, Sawamura T, Yue BY, Honda Y and Tanihara H: Effects of protein kinase inhibitor, HA1077, on intraocular pressure and outflow facility in rabbit eyes. Arch Ophthalmol 119: 1171-1178, 2001.

86. Tokushige H, Inatani M, Nemoto S, Sakaki H, Katayama K, Uehata $\mathrm{M}$ and Tanihara $\mathrm{H}$ : Effects of topical administration of Y-39983, a selective rho-associated protein kinase inhibitor, on ocular tissues in rabbits and monkeys. Invest Ophthalmol Vis Sci 48: 3216-3222, 2007.

87. Tanihara $\mathrm{H}$, Inatani $\mathrm{M}$, Honjo $\mathrm{M}$, Tokushige $\mathrm{H}$, Azuma $\mathrm{J}$ and Araie M: Intraocular pressure-lowering effects and safety of topical administration of a selective ROCK inhibitor, SNJ-1656, in healthy volunteers. Arch Ophthalmol 126: 309-315, 2008

88. Fukunaga T, Ikesugi K, Nishio M, Sugimoto M, Sasoh M, Hidaka $\mathrm{H}$ and Uji Y: The effect of the Rho-associated protein kinase inhibitor, HA-1077, in the rabbit ocular hypertension model induced by water loading. Curr Eye Res 34: 42-47, 2009.

89. Gottanka J, Chan D, Eichhorn M, Lutjen-Drecoll E and Ethier CR: Effects of TGF- $\beta 2$ in perfused human eyes. Invest Ophthalmol Vis Sci 45: 153-158, 2004.

90. Mettu PS, Deng PF, Misra UK, Gawdi G, Epstein DL and Rao PV: Role of lysophospholipid growth factors in the modulation of aqueous humor outflow facility. Invest Ophthalmol Vis Sci 45: 2263-2271, 2004.

91. Zhang M, Maddala R and Rao PV: Novel molecular insights into RhoA GTPase-induced resistance to aqueous humor outflow through the trabecular meshwork. Am J Physiol Cell Physiol 295: C1057-C1070, 2008.

92. Waki M, Yoshida Y, Oka T and Azuma M: Reduction of intraocular pressure by topical administration of an inhibitor of the Rho-associated protein kinase. Curr Eye Res 22: 470-474, 2001.

93. Wiederholt $M$ and Stumpff $H$ : The trabecular meshwork and aqueous humor reabsorption. Curr Top Membr 45: 163-202, 1998. 
94.Uehata M, Ishizaki $\mathrm{T}$, Satoh $\mathrm{H}$, Ono $\mathrm{T}$, Kawahara $\mathrm{T}$, Morishita T, Tamakawa H, Yamagami K, Inui J, Maekawa M and Narumiya S: Calcium sensitization of smooth muscle mediated by a Rho-associated protein kinase in hypertension. Nature 389: 990-994, 1997.

95. Iizuka K, Yoshii A, Samizo K, Tsukagoshi H, Ishizuka T, Dobashi K, Nakazawa T and Mori M: A major role for the rho-associated coiled coil forming protein kinase in G-proteinmediated $\mathrm{Ca}^{2+}$ sensitization through inhibition of myosin phosphatase in rabbit trachea. Br J Pharmacol 128: 925-933, 1999

96.Lütjen-Drecoll E, Futa R and Rohen JW: Ultrahistochemical studies on tangential sections of the trabecular meshwork in normal and glaucomatous eyes. Invest Ophthalmol Vis Sci 21: 563-573, 1981

97. Yue BY: The extracellular matrix and its modulation in the trabecular meshwork. Surv Ophthalmol 40: 379-390, 1996

98.Tamm ER and Fuchshofer R: What increases outflow resistance in primary open-angle glaucoma? Surv Ophthalmo 52 (Suppl 2): S101-S104, 2007.

99. Acott TS and Kelley MJ: Extracellular matrix in the trabecular meshwork. Exp Eye Res 86: 543-561, 2008.

100.Keller KE, Aga, M Bradley JM, Kelley MJ and Acott TS: Extracellular matrix turnover and outflow resistance. Exp Eye Res 88: 676-682, 2009.

101. Pattabiraman PP and Rao PV: Mechanistic basis of Rho GTPase-induced extracellular matrix synthesis in trabecular meshwork cells. Am J Physiol Cell Physiol 298: C749-763, 2010

102. Nakamura Y, Hirano S, Suzuki K, Seki K, Sagara T and Nishida T: Signaling mechanism of TGF- $\beta 1$-induced collagen contraction mediated by bovine trabecular meshwork cells Invest Ophthalmol Vis Sci 43: 3465-3472, 2002.

103. Fleenor DL, Shepard AR, Hellberg PE, Jacobson N, Pang IH and Clark AF: TGF 32 -induced changes in human trabecular meshwork: implications for intraocular pressure. Invest Ophthalmol Vis Sci 47: 226-234, 2006.

104. Iyer P, Maddala R, Pattabiraman PP and Rao PV: Connective tissue growth factor-mediated upregulation of neuromedin $\mathrm{U}$ expression in trabecular meshwork cells and its role in homeostasis of aqueous humor outflow. Invest Ophthalmol Vis Sci 53 4952-4962, 2012

105.Bershadsky AD, Balaban NQ and Geiger B: Adhesiondependent cell mechanosensitivity. Annu Rev Cell Dev Bio 19: 677-695, 2003.

106. Kaunas R, Nguyen P, Usami S and Chien S: Cooperative effects of Rho and mechanical stretch on stress fiber organization. Proc Natl Acad Sci USA 102: 15895-15900, 2005.

107. Shikata Y, Rios A, Kawkitinarong K, DePaola N, Garcia JG and Birukov KG: Differential effects of shear stress and cyclic stretch on focal adhesion remodeling, site-specific FAK phosphorylation, and small GTPases in human lung endothelia cells. Exp Cell Res 304: 40-49, 2005.

108.Ingber DE: Cellular mechanotransduction: putting all the pieces together again. FASEB J 20: 811-827, 2006.

109. Tzima E: Role of small GTPases in endothelial cytoskeletal dynamics and the shear stress response. Circ Res 98: 176-185, 2006.

110. Schlunck G, Han H, Wecker T, Kampik D, Meyer-ter-Vehn T and Grehn F: Substrate rigidity modulates cell matrix interactions and protein expression in human trabecular meshwork cells. Invest Ophthalmol Vis Sci 49: 262-269, 2008

111. Kameda $\mathrm{T}$, Inoue $\mathrm{T}$, Inatani $\mathrm{M}$, Fujimoto $\mathrm{T}$, Honjo $\mathrm{M}$, Kasaoka N, Inoue-Mochita M, Yoshimura N and Tanihara H The effect of Rho-associated protein kinase inhibitor on monkey Schlemm's canal endothelial cells. Invest Ophthalmol Vis Sci 53: 3092-3103, 2012.

112.Epstein DL, Freddo TF, Bassett-Chu S, Chung M and Karageuzian L: Influence of ethacrynic acid on outflow facility in the monkey and calf eye. Invest Ophthalmol Vis Sci 28 2067-2075, 1987.

113. Ethier CR, Read AT and Chan DW: Effects of latrunculin-B on outflow facility and trabecular meshwork structure in human eyes. Invest Ophthalmol Vis Sci 47: 1991-1998, 2006

114. Inoue T, Pattabiraman PP, Epstein DL and Rao PV: Effects of chemical inhibition of N-WASP, a critical regulator of actin polymerization on aqueous humor outflow through the conventional pathway. Exp Eye Res 90: 360-367, 2010.

115. Bill A and Svedbergh B: Scanning electron microscopic studies of the trabecular meshwork and the canal of Schlemm - an attempt to localize the main resistance to outflow of aqueous humor in man. Acta Ophthalmol (Copenh) 50: 295-320, 1972.
116. Liu Q, Wu K, Qiu, X Yang Y, Lin X and Yu M: siRNA silencing of gene expression in trabecular meshwork: RhoA siRNA reduces IOP in mice. Curr Mol Med 12: 1015-1027, 2012.

117. Tian B and Kaufman PL: Effects of the Rho kinase inhibitor Y-27632 and the phosphatase inhibitor calyculinA on outflow facility in monkeys. Exp Eye Res 80: 215-225, 2005.

118. Yu M, Chen X, Wang N, Cai S, Li N, Qiu J, Brandt CR, Kaufman PL and Liu X: H-1152 effects on intraocular pressure and trabecular meshwork morphology of rat eyes. J Ocul Pharmacol Ther 24: 373-379, 2008.

119. Nishio M, Fukunaga T, Sugimoto M, Ikesugi K, Sumi K, Hidaka $\mathrm{H}$ and Uji Y: The effect of the H-1152P, a potent Rho-associated coiled coil-formed protein kinase inhibitor, in rabbit normal and ocular hypertensive eyes.Curr Eye Res 34: 282-286, 2009

120. Whitlock NA, Harrison B, Mixon T, Yu XQ, Wilson A, Gerhardt B, Eberhart DE, Abuin A and Rice DS: Decreased intraocular pressure in mice following either pharmacological or genetic inhibition of ROCK. J Ocul Pharmacol Ther 25: $187-194,2009$

121. Lama PJ and Fechtner RD: Antifibrotics and wound healing in glaucoma surgery. Surv Ophthalmol 48: 314-346, 2003.

122. Yoon PS and Singh K: Update on antifibrotic use in glaucoma surgery, including use in trabeculectomy and glaucoma drainage implants and combined cataract and glaucoma surgery. Curr Opin Ophthalmol 15: 141-146, 2004.

123. Migdal C, Gregory W and Hitchings R: Long-term functional outcome after early surgery compared with laser and medicine in open-angle glaucoma. Ophthalmology 101: 1651-1656, 1994.

124. Khaw PT, Occleston NL, Schultz G, Grierson I, Sherwood MB and Larkin G: Activation and suppression of fibroblast function. Eye 8: 188-195, 1994.

125. Occleston NL, Daniels JT, Tarnuzzer RW, Sethi KK, Alexander RA, Bhattacharya SS, Schultz GS and Khaw PT: Single exposures to antiproliferatives: long-term effects on ocular fibroblast wound-healing behavior. Invest Ophthalmol Vis Sci 38: 1998-2007, 1997.

126. Tomasek JJ, Gabbiani G, Hinz B, Chaponnier C and Brown RA: Myofibroblasts and mechano-regulation of connective tissue remodelling. Nat Rev Mol Cell Biol 3: 349-363, 2002

127.Hinz B, Mastrangelo D, Iselin CE, Chaponnier C and Gabbiani G: Mechanical tension controls granulation tissue contractile activity and myofibroblast differentiation. Am J Pathol 159: 1009-1020, 2001

128. Desmouliere A, Chaponnier C and Gabbiani G: Tissue repair, contraction, and the myofibroblast. Wound Repair Regen 13: $7-12,2005$

129. Meyer-Ter-Vehn T, Gebhardt S, Sebald W, Buttmann M, Grehn F, Schlunck $G$ and Knaus P: p38 inhibitors prevent TGF- $\beta$-induced myofibroblast transdifferentiation in human tenon fibroblasts. Invest Ophthalmol Vis Sci 47: 1500-1509, 2006.

130. Ehrlich HP and Rajaratnam JB: Cell locomotion forces versus cell contraction forces for collagen lattice contraction: an in vitro model of wound contraction. Tissue Cell 22: 407-417, 1990.

131. Desmouliere A, Redard M, Darby I and Gabbiani G: Apoptosis mediates the decrease in cellularity during the transition between granulation tissue and scar. Am J Pathol 146: 56-66, 1995.

132. Darby IA and Hewitson TD: Fibroblast differentiation in wound healing and fibrosis. Int Rev Cytol 257: 143-179, 2007.

133. Meyer-ter-Vehn T, Sieprath S, Katzenberger B, Gebhardt S, Grehn F and Schlunck G: Contractility as a prerequisite for TGF- $\beta$-induced myofibroblast transdifferentiation in human tenon fibroblasts. Invest Ophthalmol Vis Sci 47: 4895-4904, 2006.

134. Miller MH, Grierson I, Unger WI and Hitchings RA: Wound healing in an animal model of glaucoma fistulizing surgery in the rabbit. Ophthalmic Surg 20: 350-357, 1989

135.Desmouliere A, Geinoz A, Gabbiani F and Gabbiani G: Transforming growth factor-beta 1 induces alpha-smooth muscle actin expression in granulation tissue myofibroblasts and in quiescent and growing cultured fibroblasts. J Cell Biol 122: 103-111, 1993.

136. Watsky MA: Lysophosphatidic acid, serum, and hyposmolarity activate Cl- currents in corneal keratocytes. Am J Physiol 269: C1385-C1393, 1995.

137. Cordeiro MF, Reichel MB, Gay JA, D'Esposita F, Alexander RA and Khaw PT: Transforming growth factor-beta1, -beta2, and -beta3 in vivo: effects on normal and mitomycin C-modulated conjunctival scarring. Invest Ophthalmol Vis Sci 40: $1975-1982,1999$. 
138. Cordeiro MF, Chang L, Lim KS, Daniels JT, Pleass RD, Siriwardena D and Khaw PT: Modulating conjunctival wound healing. Eye 14: 536-547, 2000.

139. Wong TT, Mead AL and Khaw PT: Matrix metalloproteinase inhibition modulates postoperative scarring after experimental glaucoma filtration surgery. Invest Ophthalmol Vis Sci 44: 1097-1103, 2003.

140.Itoh K, Yoshioka K, Akedo H, Uehata M, Ishizaki T and Narumiya S: An essential part for Rho-associated kinase in the transcellular invasion of tumor cells. Nat Med 5: 221-225, 1999.

141.Harvey SA, Anderson SC and SundarRaj N: Downstream effects of ROCK signaling in cultured human corneal stromal cells: microarray analysis of gene expression. Invest Ophthalmol Vis Sci 45: 2168-2176, 2004.

142. Yoshizaki H, Ohba Y, Parrini MC, Dulyaninova NG, Bresnick AR, Mochizuki N and Matsuda M: Cell type-specific regulation of RhoA activity during cytokinesis. J Biol Chem 279: 44756-44762, 2004

143. Tomasek JJ, Vaughan MB, Kropp BP, Gabbiani G, Martin MD, Haaksma CJ and Hinz B: Contraction of myofibroblasts in granulation tissue is dependent on Rho/Rho kinase/myosin light chain phosphatase activity. Wound Repair Regen 14: 313-320, 2006.

144.Parizi M, Howard EW and Tomasek JJ: Regulation of LPA-promoted myofibroblast contraction: role of Rho, myosin light chain kinase, and myosin light chain phosphatase. Exp Cell Res 254: 210-220, 2000.

145. Tangkijvanich P, Melton AC, Santiskulvong C and Yee HF Jr: Rho and p38 MAP kinase signaling pathways mediate LPA-stimulated hepatic myofibroblast migration. J Biomed Sci 10: 352-358, 2003.

146. Honjo M, Tanihara H, Kameda T, Kawaji, T Yoshimura N and Araie M: Potential role of Rho-associated protein kinase inhibitor Y-27632 in glaucoma filtration surgery. Invest Ophthalmol Vis Sci 48: 5549-5557, 2007.

147.Lukas TJ, Miao H, Chen L, Riordan SM, Li W, Crabb AM, Wise A, Du P, Lin SM and Hernandez MR: Susceptibility to glaucoma: differential comparison of the astrocyte transcriptome from glaucomatous African American and Caucasian American donors. Genome Biol 9: R111, 2008.

148. Hathaway DR, March KL, Lash JA, Adam LP and Wilensky RL: Vascular smooth muscle. A review of the molecular basis of contractility. Circulation 83: 382-390, 1991.

149. Savineau JP and Marthan R: Modulation of the calcium sensitivity of the smooth muscle contractile apparatus: molecular mechanisms, pharmacological and pathophysiological implications. Fundam Clin Pharmacol 11: 289-299, 1997.

150. Mita M, Yanagihara H, Hishinuma S, Saito M and Walsh MP Membrane depolarization-induced contraction of rat caudal arterial smooth muscle involves Rho-associated kinase. Biochem J 364: 431-440, 2002.

151. Sward K, Mita M, Wilson DP, Deng JT, Susnjar M and Walsh MP: The role of RhoA and Rho-associated kinase in vascular smooth muscle contraction. Curr Hypertens Rep 5: 66-72, 2003

152. Kandabashi T, Shimokawa H, Miyata K, Kunihiro I, Kawano Y, Fukata Y, Higo T, Egashira K, Takahashi S, Kaibuchi K and Takeshita A: Inhibition of myosin phosphatase by upregulated rho-kinase plays a key role for coronary artery spasm in a porcine model with interleukin-1beta. Circulation 101: 1319-1323, 2000.

153. Sato M, Tani E, Fujikawa $\mathrm{H}$ and Kaibuchi K: Involvement of Rho-kinase-mediated phosphorylation of myosin light chain in enhancement of cerebral vasospasm. Circ Res 87: 195-200, 2000

154.Iizuka K, Shimizu Y, Tsukagoshi H, Yoshii A, Harada T, Dobashi K, Murozono T, Nakazawa T and Mori M: Evaluation of Y-27632, a rho-kinase inhibitor, as a bronchodilator in guinea pigs. Eur J Pharmacol 406: 273-279, 2000.

155. Chitaley K, Wingard CJ, Clinton Webb R, Branam H, Stopper VS, Lewis RW and Mills TM: Antagonism of Rho-kinase stimulates rat penile erection via a nitric oxideindependent pathway. Nat Med 7: 119-122, 2001.

156. Takahashi R, Nishimura J, Hirano K, Seki N, Naito S and Kanaide $\mathrm{H}: \mathrm{Ca}^{2+}$ sensitization in contraction of human bladder smooth muscle. J Urol 172: 748-752, 2004

157. Schubert R, Kalentchuk VU and Krien U: Rho kinase inhibition partly weakens myogenic reactivity in rat small arteries by changing calcium sensitivity. Am J Physiol Heart Circ Physiol 283: H2288-H2295, 2002.
158. Cavarape A, Bauer J, Bartoli E, Endlich K and Parekh N: Effects of angiotensin II, arginine vasopressin and tromboxane A2 in renal vascular bed: role of rho-kinase. Nephrol Dial Transplant 18: 1764-1769, 2003.

159. Cavarape A, Endlich N, Assaloni R, Bartoli E, Steinhausen M, Parekh N and Endlich K: Rho-kinase inhibition blunts renal vasoconstriction induced by distinct signaling pathways in vivo. J Am Soc Nephrol 14: 37-45, 2003.

160. Randriamboavonjy V, Busse R and Fleming I: 20-HETE-induced contraction of small coronary arteries depends on the activation of Rho-kinase. Hypertension 41: 801-806, 2003.

161. Watabe H, Abe S and Yoshitomi T: Effects of Rho-associated protein kinase inhibitors Y-27632 and Y-39983 on isolated rabbit ciliary arteries. Jpn J Ophthalmol 55: 411-417, 2011.

162. Tokushige H: ROCK inhibitor and glaucoma. Bio Clinica 17: 1191-1194, 2002.

163. Sugiyama T, Shibata M, Kajiura S, Okuno T, Tonari M, Oku H and Ikeda T: Effects of fasudil, a Rho-associated protein kinase inhibitor, on optic nerve head blood flow in rabbits. Invest Ophthalmol Vis Sci 52: 64-69, 2011

164.Okamura N, Saito M, Mori A, Sakamoto K, Kametaka S, Nakahara $\mathrm{T}$ and Ishii K: Vasodilator effects of fasudil, a Rho-kinase inhibitor, on retinal arterioles in stroke-prone spontaneously hypertensive rats. J Ocul Pharmacol Ther 23: 207-212, 2007.

165. Wolfrum S, Dendorfer A, Rikitake Y, Stalker TJ, Gong Y, Scalia R, Dominiak P and Liao JK: Inhibition of Rho-kinase leads to rapid activation of phosphatidylinositol 3-kinase/protein kinase Akt and cardiovascular protection. Arterioscler Thromb Vasc Biol 24: 1842-1847, 2004.

166. Anderson DR: Introductory comments on blood flow autoregulation in the optic nerve head and vascular risk factors in glaucoma. Surv Ophthalmol 43: S5-S9, 1999.

167. Chung HS, Harris A, Evans DW, Kagemann L, Garzozi HJ and Martin B: Vascular aspects in the pathophysiology of glaucomatous optic neuropathy. Surv Ophthalmol 43: S43-S50, 1999.

168. Flammer J, Orgul S, Costa VP, Orzalesi N, Krieglstein GK, Serra LM, Renard JP and Stefansson E: The impact of ocular blood flow in glaucoma. Prog Retin Eye Res 21: 359-393, 2002.

169. Ben Simon GJ, Moroz I, Goldenfeld M and Melamed S: Scanning laser Doppler flowmetry of nonperfused regions of the optic nerve head in patients with glaucoma. Ophthalmic Surg Lasers Imaging 34: 245-250, 2003.

170. Hu Y, Cui Q and Harvey AR: Interactive effects of C3, cyclic AMP and ciliaryneurotrophic factor on adult retinal ganglion cell survival and axonal regeneration. Mol Cell Neurosci 34: 88-98, 2007.

171. Kitaoka Y, Kitaoka Y, Kumai T, Lam TT, Kuribayashi K, Isenoumi K, Munemasa Y, Motoki M, Kobayashi S and Ueno S: Involvement of RhoA and possible neuroprotective effect of fasudil, a Rho kinase inhibitor, in NMDA-induced neurotoxicity in the rat retina. Brain Res 1018: 111-118, 2004.

172. Bertrand J, Di Polo A and McKerracher L: Enhanced survival and regeneration of axotomized retinal neurons by repeated delivery of cell-permeable C3-like Rho antagonists. Neurobiol Dis 25: 65-72, 2007.

173. Sheikh AM, Nagai A, Ryu JK, McLarnon JG, Kim SU and Masuda J: Lysophosphatidylcholine induces glial cell activation: role of rho kinase. Glia 57: 898-907, 2009.

174. Buchi ER: Cell death in the rat retina after a pressure-induced ischaemia-reperfusion insult: an electron microscopic study. I. Ganglion cell layer and inner nuclear layer. Exp Eye Res 55: 605-613, 1992

175. Rosenbaum DM, Rosenbaum PS, Gupta A, Michaelson MD, Hall DH and Kessler JA: Retinal ischemia leads to apoptosis which is ameliorated by aurintricarboxylic acid. Vision Res 37: 3445-3451, 1997.

176. Hirooka K, Miyamoto O, Jinming P, Du Y, Itano T, Baba T, Tokuda $M$ and Shiraga F: Neuroprotective effects of D-allose against retinal ischemia-reperfusion injury. Invest Ophthalmol Vis Sci 47: 1653-1657, 2006.

177. Millán J and Ridley AJ: Free in PMC Rho GTPases and leucocyte-induced endothelial remodelling. Biochem J 385: 329-337, 2005

178. Wittchen ES, van Buul JD, Burridge K and Worthylake RA: Trading spaces: Rap, Rac, and Rho as architects of transendothelial migration. Curr Opin Hematol 12: 14-21, 2005.

179. Song H and Gao D: Fasudil, a Rho-associated protein kinase inhibitor, attenuates retinal ischemia and reperfusion injury in rats. Int J Mol Med 28: 193-198, 2011. 
180. Tsujikawa A, Ogura Y, Hiroshiba N, Miyamoto K, Kiryu J, Tojo SJ, Miyasaka M and Honda Y: Retinal ischemia-reperfusion injury attenuated by blocking of adhesion molecules of vascular endothelium. Invest Ophthalmol Vis Sci 40: 1183-1190, 1999.

181.Hirata A, Inatani M, Inomata Y, Yonemura N, Kawaji T, Honjo M and Tanihara H: Y-27632, a Rho-associated protein kinase inhibitor, attenuates neuronal cell death after transient retinal ischemia. Graefes Arch Clin Exp Ophthalmol 246: 51-59, 2008.

182.Lingor P, Tönges L, Pieper N, Bermel C, Barski E, Planchamp V and Bähr M: ROCK inhibition and CNTF interact on intrinsic signalling pathways and differentially regulate survival and regeneration in retinal ganglion cells. Brain 131: 250-263, 2008.

183. Tura A, Schuettauf F, Monnier PP, Bartz-Schmidt KU and Henke-Fahle S: Efficacy of Rho-kinase inhibition in promoting cell survival and reducing reactive gliosis in the rodent retina. Invest Ophthalmol Vis Sci 50: 452-461, 2009.

184.Fournier AE, GrandPre T, Gould G, Wang $X$ and Strittmatter SM: Nogo and the Nogo-66 receptor. Prog Brain Res 137: 361-369, 2002.

185. Hunt D, Coffin RS and Anderson PN: The Nogo receptor, its ligands and axonal regeneration in the spinal cord; a review. J Neurocytol 31: 93-120, 2002.

186. McKerracher L and Winton MJ: Nogo on the go. Neuron 36: 345-348, 2002.

187. Sandvig A, Berry M, Barrett LB, Butt A and Logan A: Myelin-, reactive glia-, and scar-derived $\mathrm{CNS}$ axon growth inhibitors: expression, receptor signaling, and correlation with axon regeneration. Glia 46: 225-251, 2004.

188. Fawcett JW: Overcoming inhibition in the damaged spinal cord. J Neurotrauma 23: 371-383, 2006.

189.Du J, Fu C and Sretavan DW: Eph/ephrin signaling as a potential therapeutic target after central nervous system injury. Curr Pharm Des 13: 2507-2518, 2007.

190. Fabes J, Anderson P, Brennan C and Bolsove S: Regenerationenhancing effects of EphA4 blocking peptide following corticospinal tract injury in adult rat spinal cord. Eur $\mathbf{J}$ Neurosci 26: 2496-2505, 2007.
191. Hou ST, Jiang SX and Smith RA: Permissive and repulsive cues and signalling pathways of axonal outgrowth and regeneration. Int Rev Cell Molec Biol 267: 125-181, 2008.

192. Berry M, Ahmed Z, Lorber B, Douglas M and Logan A Regeneration of axons in the visual system. Restor Neurol Neurosci 26: 147-174, 2008.

193. Bertrand J, Winton MJ, Rodriguez-Hernandez N, Campenot RB and McKerracher L: Application of Rho antagonist to neuronal cell bodies promotes neurite growth in compartmented cultures and regeneration of retinal ganglion cell axons in the optic nerve of adult rats. J Neurosci 25: 1113-1121, 2005.

194. Sagawa H, Terasaki H, Nakamura M, Ichikawa M, Yata T, Tokita Y and Watanabe M: A novel ROCK inhibitor, Y-39983, promotes regeneration of crushed axons of retinal ganglion cells into the optic nerve of adult cats. Exp Neurol 205: 230-240, 2007.

195. Monnier PP, Sierra A, Schwab JM, Henke-Fahle S and Mueller BK: The Rho/ROCK pathway mediates neurite growth-inhibitory activity associated with the chondroitin sulfate proteoglycans of the CNS glial scar. Mol Cell Neurosci 22: 319-330, 2003

196.Lingor P, Teusch N, Schwarz K, Mueller R, Mack H, Bahr M and Mueller BK: Inhibition of Rho kinase (ROCK) increases neurite outgrowth on chondroitin sulphate proteoglycan in vitro and axonal regeneration in the adult optic nerve in vivo. J Neurochem 103: 181-189, 2007.

197. Ahmed Z, Berry M and Logan A: ROCK inhibition promotes adult retinal ganglion cell neurite outgrowth only in the presence of growth promoting factors. Mol Cell Neurosci 42: 128-133, 2009.

198. Watanabe M: Regeneration of optic nerve fibers of adult mammals. Dev Growth Differ 52: 567-576, 2010.

199. Tan H, Zhong Y, Shen X, Cheng Y, Jiao Q and Deng L: Erythropoietin promotes axonal regeneration after optic nerve crush in vivo by inhibition of RhoA/ROCK signaling pathway. Neuropharmacology 63: 1182-1190, 2012. 